\title{
OPEN
}

Published online: 15 January 2020

\section{Author Correction: Establishment of a novel human CIC-DUX4 sarcoma cell line, Kitra-SRS, with autocrine IGF-1R activation and metastatic potential to the lungs}

Sho Nakai, Shutaro Yamada, Hidetatsu Outani, Takaaki Nakai, Naohiro Yasuda, Hirokazu Mae, Yoshinori Imura, Toru Wakamatsu, Hironari Tamiya, Takaaki Tanaka, Kenichiro Hamada, Akiyoshi Tani, Akira Myoui, Nobuhito Araki, Takafumi Ueda, HidekiYoshikawa, Satoshi Takenaka \& Norifumi Naka

Correction to: Scientific Reports https://doi.org/10.1038/s41598-019-52143-3, published online 01 November 2019

The original version of this Article contained an error throughout the Article, where the number "4" was incorrectly subscripted in "DUX4". This has now been corrected in the PDF and HTML versions of the Article. The Supplementary Information file was correct at time of publication.

(i) Open Access This article is licensed under a Creative Commons Attribution 4.0 International License, which permits use, sharing, adaptation, distribution and reproduction in any medium or format, as long as you give appropriate credit to the original author(s) and the source, provide a link to the Creative Commons license, and indicate if changes were made. The images or other third party material in this article are included in the article's Creative Commons license, unless indicated otherwise in a credit line to the material. If material is not included in the article's Creative Commons license and your intended use is not permitted by statutory regulation or exceeds the permitted use, you will need to obtain permission directly from the copyright holder. To view a copy of this license, visit http://creativecommons.org/licenses/by/4.0/.

(C) The Author(s) 2020 